\title{
Governing health professional mobility in the European Union
}

\author{
Matthias Wismar \\ From Health Services Research: Evidence-based practice \\ London, UK. 1-3 July 2014
}

Health professional mobility in Europe has become a fast-moving target for policy-makers. It is evolving rapidly in direction and magnitude as a consequence of fundamental change caused by European Union (EU) enlargement and the financial and economic crisis.

Health professional mobility changes the numbers of health professionals in countries and the skill-mix of the workforce, with consequences for health-system performance. Many of the so-called pull and push factors influencing mobility of individuals are in the remit of countries and organizations. In Europe, these pull and push factors are co-determined by EU policies on free mobility, the qualifications directive and many soft-law initiatives.

This presentation is reviewing the current mobility trends in Europe and provides clues on how to strengthen governance for human resources for health at European and country level. A particular reference is made to mobility monitoring, workforce intelligence, workforce policies/ strategies, skills-initiatives and coordination mechanisms across sectors and levels.

Published: 7 July 2014

Submit your next manuscript to BioMed Central and take full advantage of:

- Convenient online submission

- Thorough peer review

- No space constraints or color figure charges

- Immediate publication on acceptance

- Inclusion in PubMed, CAS, Scopus and Google Scholar

- Research which is freely available for redistribution 